\title{
King's Score may be More Effective in the Determination of Severe Fibrosis in Chronic Hepatitis B Infections
}

\section{Kronik Hepatit B Enfeksiyonunda Șiddetli Fibrozisi Belirlemede King Skoru Daha Etkin Olabilir}

\author{
Zehra KARACAER¹, Özgür AVCI2, Fatma YILMAZ KARADAĞ3 \\ ${ }^{1}$ Gülhane Training and Research Hospital, Clinic of Infectious Diseases and Clinical Microbiology, Ankara, Turkey \\ 2Etimesgut Sait Ertürk State Hospital, Clinic of Biochemistry, Ankara, Turkey \\ 3/stanbul Medeniyet University, Göztepe Training and Research Hospital, Clinic of Infectious Diseases and Clinical Microbiology, Istanbul, Turkey
}

\begin{abstract}
Objective: The objective of this study was to compare the performances of several noninvasive indirect biochemical markers used to detect advanced fibrosis in patients with chronic hepatitis $\mathrm{B}(\mathrm{CHB})$.

Materials and Methods: This study was retrospectively conducted in two centers, and included treatment-naive $\mathrm{CHB}$ patients undergoing liver needle biopsies. The following noninvasive biochemical markers were used: the aspartate aminotransferase to platelets ratio index (APRI), Fibrosis 4 (FIB-4) index, Goteborg University Cirrhosis index (GUCl), King's score, FibroQ score, aspartate aminotransferase to alanine aminotransferase ratio (AAR), Cirrhosis Discriminant Score (CDS) Bonacini, and age-platelet (AP) index.

Results: This study included a total of 255 patients ( $79.6 \%$ males), with a median age of 27 years (19-69). The AAR did not show a significant difference in predicting severe fibrosis according to the area under the curve (AUC) and $p$ values ( $A \cup C=0.493, p=0.887$ ) of the non-invasive methods. Overall, the APRI, FIB-4, GUCl, and King' score were more effective (all $p$ values $<0.001$; AUC values: 0.787, $0.768,0.775$, and 0.807; respectively).

Conclusion: In our study group, the highest AUC and positive likelihood ratio $(L R+)$ values were found using King's score. Therefore, King's score seems to be more selective in the classification of patients with severe fibrosis among CHB patients, because of its higher correct predictive value.

Keywords: Chronic hepatitis B, fibrosis, non-invasive, King's score
\end{abstract}

ÖZ

Amaç: Bu çalışmada kronik hepatit B'li (KHB) hastalarda ileri dönem fibrozisi tespit etmede kullanılan bazı non-invaziv indirekt biyokimyasal belirteçlerin performanslarının karşılaştıııması amaçlanmışıı. Gereç ve Yöntemler: Bu çalışma retrospektif olarak iki merkezde gerçekleştirilmiştir ve karaciğer iğne biyopsisi yapılan, naiv, KHB hastaları dahil edilmiştir. Non-invaziv biyokimyasal belirteçlerden aspartat aminotransaminaz - Platelet Ratio Index (APRI), Fibrosis 4 (FIB-4) Index, Goteborg University Cirrhosis Index (GUCl), King skoru, FibroO skoru, aspartat aminotransaminaz - alanin aminotransaminaz ratio (AAR), Cirrhosis Discriminate Score (CDS) Bonacini, age-platelet (AP) index kullanılmıştır.

Bulgular: Çalışmaya \%79,6'sı erkek olmak üzere 255 hasta dahil edilmiştir. Yaş ortanca değeri 27 (19-69) yıl olarak hesaplanmıştır. Non-invaziv yöntemlerin eğri altında kalan alan (AUC) ve $p$ değerlerine göre $A A R$ 'nin şiddetli fibrosisi belirlemede anlamlı fark oluşturmadığı ( $A \cup C=0,493, p=0,887$ ), APRI, FIB-4, $G U C l$ ve King metodlarının diğerlerinden daha etkili yöntemler olduğu saptanmıştır ( $p$ değerleri hepsinde $<0,001$; sırasıyla, AUC değerleri: 0,787, 0,768, $0,775,0,807)$

Sonuç: Çalışma grubumuzda King skoru ile en yüksek AUC ve pozitif likelihood ratio $(L R+)$ elde edilmiştir. Doğru tahmin değerinin daha yüksek olması nedeniyle KHB hastalarında King skorunun şiddetli fibrozis hastalarını sınıflandırmada daha seçici olduğu söylenebilir. Anahtar Kelimeler: Kronik hepatit B, fibrozis, non-invaziv, King skoru

Karacaer Z, Avcı Ö, Yılmaz Karadağ F. King's Score may be More Effective in the Determination of Severe Fibrosis in Chronic Hepatitis B Infections. Viral Hepat J. 2017;23:20-25.

Address for Correspondence: Zehra Karacaer MD, Gülhane Training and Research Hospital, Clinic of Infectious Diseases and Clinical Microbiology, Ankara, Turkey Phone: +90 3123042000 E-mail: zehrakaracaer@yahoo.com Received: 25.04.2017 Accepted: 27.04.2017 


\section{Introduction}

Development of fibrosis and cirrhosis in the liver plays an important role in the management of patients with chronic hepatitis $\mathrm{B}(\mathrm{CHB})$. Evaluation of fibrosis in patients with $\mathrm{CHB}$ is required in the determination of both the prognosis and the need for treatment (1). Fibrosis is a nonspecific response to liver damage, with the synthesis of extracellular matrix. The ideal markers of liver fibrosis should have liver-specific, non-invasive, easy to apply, and rapid features, with measurable sensitivity and reproducibility. In addition, they should have features that enable monitoring the progression or regression of fibrosis during the natural course of the disease, or while the patient is under treatment. The serum levels of these markers should not be affected by the changes in the liver, kidney, and reticuloendothelial system functions. In addition, statistically, the area under curve (AUC) value should be as close to 1.0 as possible, and the sensitivity and specificity values should be close to $100 \%$. The AUC values of the vast majority of biochemical markers are between 0.80 and 0.85 , and those markers are more helpful in distinguishing low and high fibrosis rather than staging liver damage (2).

The advantages of biochemical markers include reproducibility, easy accessibility, low costs, and applicability in patients who can be treated on an outpatient basis. However, most biochemical markers are not liver specific, and cannot distinguish moderate fibrosis. Moreover, their effectiveness is limited in conditions such as Gilbert's syndrome, hemolysis, and inflammation. Overall, the performance of biochemical markers in the evaluation of cirrhosis is lower than the physical methods used to measure liver stiffness (1). However, most non-invasive methods cannot distinguish between the early stages of fibrosis, so the goal of these methods is to determine the presence of cirrhosis. Currently, there are no biomarkers that can be used instead of a liver biopsy in the determination of advanced fibrosis. Nevertheless, these methods could provide guidance in the identification of those patients requiring biopsies (3).

The objectives of this study were to compare the performances of several noninvasive indirect biochemical markers used in the detection of advanced fibrosis in CHB patients, and to reveal the best method for the determination of biopsy indications.

\section{Materials and Methods}

\section{Patients}

This study was retrospectively performed in two centers at the second and tertiary levels. It includes treatment-naive $\mathrm{CHB}$ patients who presented to the Infectious diseases and clinical microbiology clinics between 01/01/2015 and 01/06/2016 and underwent liver needle biopsies. Patients with hepatitis $C$ or hepatitis $D$, those with hepatitis B infections, who received antiviral therapy, and those reported to have insufficient biopsy material were excluded from the study. Patients positive for hepatitis B surface antigen, those with a normal or high alanine aminotransferase (ALT) level for six months, and those positive for hepatitis B virus (HBV) DNA were diagnosed with $\mathrm{CHB}$.

Each patient's age and gender, as well as Aspartate aminotransferase (AST), ALT, international normalized ratio (INR), complete blood count, virological, and histopathological outcomes were retrospectively obtained from the patient files. This research was approved by the Etimesgut Military Hospital's Local Ethics Committee (07.07.2015-2015/21).

\section{Liver Histology}

Grading and staging of all of the liver biopsy materials were performed using the modified Ishak-modified Histologic Activity Index Grading and Staging System (4). Patients with a fibrosis score from 0 to 2 were considered to have a low level of fibrosis, while those with a score from 3 to 6 had marked fibrosis.

\section{Non-invasive Indirect Biochemical Markers}

In this study, among the noninvasive biochemical markers available, the AST-to-platelet ratio index (APRI), Fibrosis-4 (FIB4) index, Goteborg University Cirrhosis Index (GUCl), King's score, FibroQ score, AST to ALT ratio (AAR), Bonacini Cirrhosis Discriminant Score (CDS), and age-platelet index (AP) were used $(5,6,7,8,9,10,11,12)$. The formulas for these methods are shown in Table 1.

The following cut-off values for the absence of fibrosis have been reported by the researchers who formulated these methods:

\begin{tabular}{|c|c|c|c|c|c|c|c|c|}
\hline Methods & \multicolumn{8}{|l|}{ Formula } \\
\hline APRI & \multicolumn{8}{|c|}{ (AST, upper limit of normal) / platelet count (109/ L) x 100} \\
\hline FIB-4 & \multicolumn{8}{|c|}{ Age (year) $\times$ AST (U/L) / platelet count $\left(10^{9} / \mathrm{L}\right) \times$ ALT $(\mathrm{U} / \mathrm{L})^{1 / 2}$} \\
\hline GUCl & \multicolumn{8}{|c|}{ Normalized AST (U/L) x INR x $100 /$ platelet count (109/L) } \\
\hline King & \multicolumn{8}{|c|}{ Age (years) x AST (IU/L) x INR / platelet count (109/L) } \\
\hline FibroQ & \multicolumn{8}{|c|}{ [10 $\times$ age $\left(\right.$ years) $\times$ AST $\times$ INR)/ (platelet count $\left(10^{9} / \mathrm{L}\right) \times$ ALT] } \\
\hline AAR & \multicolumn{8}{|l|}{ AST (U/L) /ALT (U/L) } \\
\hline \multicolumn{9}{|l|}{ CDS } \\
\hline & Parametes & 0 & 1 & 2 & 3 & 4 & 5 & 6 \\
\hline & INR & $<1.1$ & 1.1-1.4 & $>1.4$ & & & & \\
\hline & ALT/AST ratio & $>1.7$ & $1.7-1.2$ & $1.19-0.6$ & $<0.6$ & & & \\
\hline & Platelet count $\left(x 1000 / \mathrm{mm}^{3}\right)$ & $>340$ & $340-280$ & $279-220$ & 219-160 & $159-100$ & $99-40$ & $<40$ \\
\hline \multicolumn{9}{|l|}{ AP } \\
\hline & Age (year) & $<30$ & $30-39$ & $40-49$ & $50-59$ & $60-69$ & $>70$ & \\
\hline & Platelet count $\left(\times 1000 / \mathrm{mm}^{3}\right)$ & $>225$ & $200-224$ & $175-199$ & $150-174$ & $125-149$ & $<125$ & \\
\hline
\end{tabular}


APRI $\leq 0.5$ (5), FIB-4 $<1.45$ (6), GUCl $<0.2$ (7), King's score $\geq 12.3$ (8), and FibroO score $<1.6$ (9). For marked fibrosis, the following cut-off values were determined by the same researchers: $>1.5$, $>3.25, \geq 1.0, \geq 16.7$, and $\geq 1.6$ for the APRI, FIB-4, GUCl, King's score, and FibroQ score, respectively. The rest of the cut-off values were found in other studies, as follows: $A A R \geq 1$ (10), $C D S \geq 8$ (11), and AP index $\geq 6$ (12).

\section{Statistical Analysis}

Statistical analysis was performed using SPSS IBM 22.0 (SPSS Inc., Chicago, IL, USA). The normal distribution of the variables was determined using the Kolmogorov-Smirnov test. Because of their non-normal distribution, the continuous variables were obtained as the median (min-max). The categorical variables were presented as the frequency and percentage.

The AUC was found using a receiver operating characteristics analysis in order to determine the effectiveness of the methods used in showing marked fibrosis. An AUC of $\leq 0.5$ was evaluated as "the test has no diagnostic value". The highest cut-off value giving the sum of the sensitivity and specificity-1 values was found in order to estimate the best compliance between the sensitivity and specificity. The performances of these methods in the determination of fibrosis were evaluated by first using the cut-off values found in this study, and then the cut-off values determined by the researchers who developed the formulas. The sensitivity, specificity, negative predictive value $(N P V)$, positive predictive value (PPV), diagnostic accuracy (DA), positive likelihood ratio $(\mathrm{LR}+)$, and negative likelihood ratio (LR-) were calculated. A $p$ value of less than 0.05 was considered statistically significant.

\section{Results}

This study included a total of 255 patients $(79.6 \%$ males) with a median age of 27 (19-69) years. And a median HBV DNA value of $72,000\left(0-9.9 \times 10^{9}\right) \mathrm{IU} / \mathrm{mL}$. Of the 255 patients, $57.3 \%$ were negative for the hepatitis B e antigen (HBeAg). The patients' laboratory and histopathological data and noninvasive test outcomes are shown in Table 2.

When the outcomes of the noninvasive biochemical methods were evaluated, the AUC value for determining significant fibrosis was highest with King's score (Figure 1). However, it was seen that the AUC value of the AAR was the lowest ( $A \cup C=0.493$ ), and did not produce a significant difference in the determination of severe fibrosis ( $\mathrm{p}=0.887$ ) (Figure 2). In addition, this method was found to be more unsuccessful in the detection of severe fibrosis, according to the cut-off value, than the other methods. According to the other cut-off values of this study, similar values were obtained using the APRI, GUCl, FIB-4, and King's score, which were more efficient in the detection of fibrosis than the other methods (Table 3).

When the performances of the methods used in this study were evaluated with the cut-off values reported in the literature, there were no scores $\geq 1$ with the GUCl method or $>8$ with the CDS method. In addition, the specificity, PPV, DA, and LR+ values were higher, and the sensitivity and NPV values were lower than our values (Table 3).

\section{Discussion}

Certain parameters (such as the AST, ALT, platelet count, and PT/INR) that show the changes in liver function can be detected with routine blood testing (1). There are multiple causes of thrombocytopenia in chronic liver disease. Splenic sequestration of platelets, suppression of their production in the bone marrow, or a decrease in the hematopoietic growth factor (thrombopoietin) activity can reduce the platelet count (13). In advanced liver disease, an increase in AST level is due to a decrease in the clearance or increase in the release of AST as a result of mitochondrial damage. Prothrombin time reflects the synthesis function of the liver, and is one of the earliest markers of cirrhosis (2). In addition to these parameters, the patient's demographic features can also be markers of liver damage. For instance, the severity of fibrosis increases with advanced age, especially in patients negative for HBeAg (14).

In this study, AST, platelet count, age, and INR were found to be more successful in the detection of severe fibrosis. Moreover,

\begin{tabular}{|c|c|c|}
\hline Variables & Median & Minimum-Maximum \\
\hline Age (year) & 27 & $19-69$ \\
\hline \multicolumn{3}{|l|}{ Sex } \\
\hline Male (n/\%) & $179 / 79.6$ & \\
\hline Female $(\mathrm{n} / \%)$ & $46 / 20.4$ & \\
\hline HBeAg negative ( $n / \%)$ & $129 / 57.3$ & \\
\hline HBV DNA (IU/mL) & 72000 & $0-9.9 \times 10^{9}$ \\
\hline Platelet count $\left(10^{3} / \mu \mathrm{L}\right)$ & 234 & $80-431$ \\
\hline INR & 1.04 & $0.8-1.46$ \\
\hline AST (U/L) & 32 & $11-503$ \\
\hline ALT (U/L) & 52 & $10-1053$ \\
\hline APRI & 0.41 & $0.11-7.38$ \\
\hline FIB-4 & 0.57 & $0.10-6.21$ \\
\hline GUCl & 0.22 & $0.13-0.67$ \\
\hline King & 4.4 & $1.31-156.12$ \\
\hline FibroQ & 0.84 & $0.07-6.59$ \\
\hline AAR & 0.65 & $0.08-2.66$ \\
\hline CDS & 3 & $0-8$ \\
\hline AP & 1 & $0-9$ \\
\hline Fibrosis scores & 1 & $0-5$ \\
\hline F0-2 (n/\%) & $185 / 82.2$ & \\
\hline F3-6 (n/\%) & $40 / 17.8$ & \\
\hline HAl scores & 5 & $0-15$ \\
\hline G0-7 (n/\%) & $186 / 82.7$ & \\
\hline G7-18 (n/\%) & $39 / 17.3$ & \\
\hline \multicolumn{3}{|c|}{$\begin{array}{l}\text { HBeAg: Hepatitis B e antigen, INR: International normalised ratio, AST } \\
\text { Aspartate aminotransferase, ALT: Alanine aminotransferase, APRI: Aspartate } \\
\text { aminotransferase to platelets ratio, FIB-4: Fibrosis-4 inde, GUCI: Goteborc } \\
\text { University Cirrhosis Index, AAR: Aspartate aminotransferase - alanine } \\
\text { aminotransferase ratio, CDS: Cirrhosis discriminant score, AP: Age-platele } \\
\text { index; HAl: Histological activity index }\end{array}$} \\
\hline
\end{tabular}




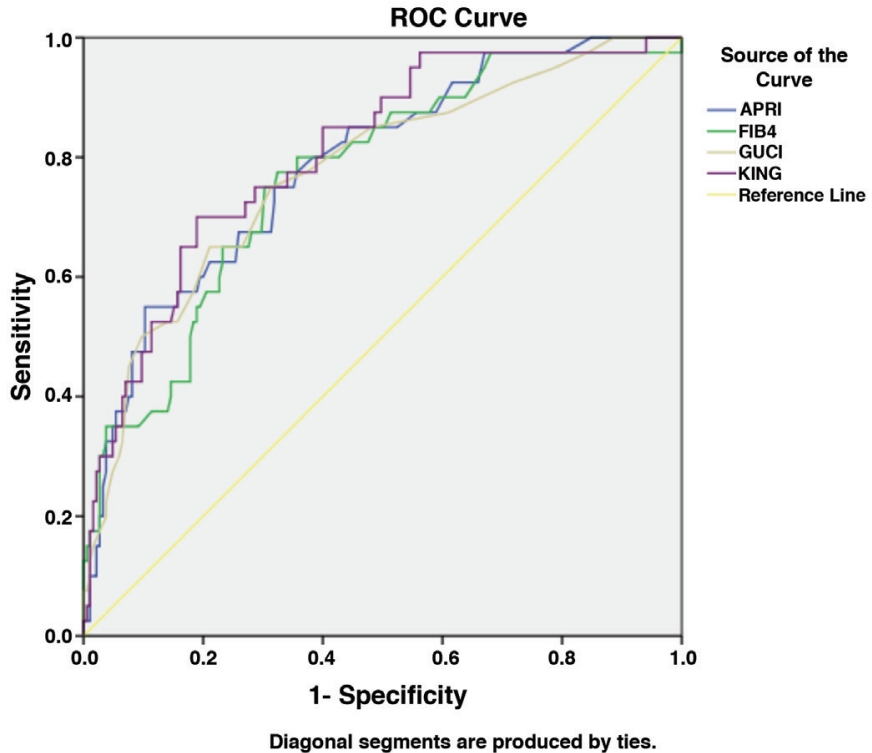

Figure 1. Receiver operating characteristics curves for aspartate aminotransferase to platelets ratio, Fibrosis-4 index, Goteborg University Cirrhosis Index, and King's score for severe fibrosis. King's score had a significantly higher area under the curve than others for the determination of severe fibrosis (F3-6)

ROC: Receiver operating characteristics, APRI: Aspartate aminotransferase to platelets ratio, FIB-4: Fibrosis-4 index, GUCl: Goteborg University Cirrhosis Index

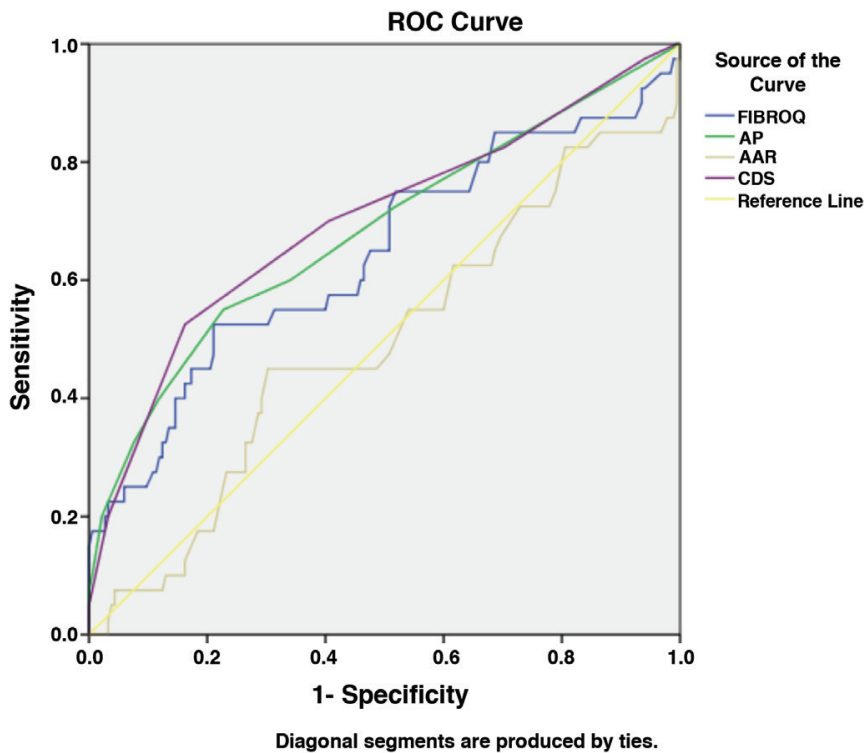

Figure 2. Receiver operating characteristics curves for FIBROQ, ageplatelet, aspartate aminotransferase- alanine aminotransferase ratio, and cirrhosis discriminant score for severe fibrosis. The area under the curve value of the aspartate aminotransferase- alanine aminotransferase ratio was the lowest and did not produce a significant difference in the determination of severe fibrosis (F3-6)

ROC: Receiver operating characteristics, AP: Age-platelet index, AAR: Aspartate aminotransferase - alanine aminotransferase ratio, CDS: Cirrhosis discriminant score

\begin{tabular}{|c|c|c|c|c|c|c|c|c|c|c|}
\hline Methods & Cut-off values & AUC $(95 \% \mathrm{CI})$ & $p$ value & Sensitivity (\%) & Specificity (\%) & NPV (\%) & PPV (\%) & DA (\%) & LR+ & LR- \\
\hline \multirow[t]{2}{*}{ APRI } & $0.47^{*}$ & $0.787(0.710-0.863)$ & $<0.001$ & 72 & 68 & 92 & 33 & 69 & 2.3 & 0.4 \\
\hline & $>1.5$ & & & 30 & 96.2 & 86.1 & 63.2 & 84 & 7.9 & 0.7 \\
\hline FIB-4 & $0.73 *$ & $0.768(0.688-0.849)$ & $<0.001$ & 75 & 70 & 92.8 & 34.9 & 71 & 2.5 & 0.4 \\
\hline \multirow[t]{3}{*}{$\mathrm{GUCl}$} & $0.24^{*}$ & $0.775(0.693-0.857)$ & $<0.001$ & 75 & 69 & 92.7 & 34.1 & 70 & 2.4 & 0.4 \\
\hline & $>0.2$ & & & 92.5 & 28.1 & 94.5 & 21.8 & 40 & 1.4 & 0.3 \\
\hline & $\geq 1$ & & & NA & NA & NA & NA & NA & NA & NA \\
\hline King & $5.76^{*}$ & $0.807(0.734-0.880)$ & $<0.001$ & 73 & 73 & 92.4 & 36.3 & 72 & 2.6 & 0.4 \\
\hline \multirow[t]{2}{*}{ AAR } & $0.6^{*}$ & $0.493(0.389-0.597)$ & 0.887 & 52.5 & 47 & 82.1 & 17.6 & 48 & 1 & 1 \\
\hline & $\geq 1$ & & & 10 & 83.8 & 81.2 & 11.8 & 71 & 0.7 & 1.1 \\
\hline \multirow[t]{2}{*}{ CDS } & $3 *$ & $0.700(0.600-0.799)$ & $<0.001$ & 70 & 59.5 & 90.2 & 27.2 & 61 & 1.7 & 0.5 \\
\hline & $\geq 8$ & & & NA & NA & NA & NA & NA & NA & NA \\
\hline \multirow[t]{2}{*}{ AP } & $0.5^{*}$ & $0.683(0.581-0.784)$ & $<0.001$ & 72.5 & 48.1 & 89 & 23.2 & 52 & 1.4 & 0.6 \\
\hline & $\geq 6$ & & & 20 & 97.8 & 85 & 66.7 & 84 & 20 & 0.9 \\
\hline \multicolumn{11}{|c|}{$\begin{array}{l}\text { AUC: Area under the curve, Cl: Confidence interval, NPV: Negative predictive value, PPV: Positive predictive value, DA: Diagnostic accuracy, LR+: Positive likelihood rati } \\
\text { LR-: Negative likelihood ratio, APRI: Aspartate aminotransferase to platelets ratio, FIB-4: Fibrosis-4 index, GUCl: Goteborg University Cirrhosis Index, AAR: Aspartat } \\
\text { aminotransferase - alanine aminotransferase ratio, CDS: Cirrhosis discriminant score, AP: Age-platelet index, NA: Not available, * our cut-off value, others are th } \\
\text { literateurs'cut-off }\end{array}$} \\
\hline
\end{tabular}


NPV, PPV, sensitivity, specificity, and LR+ values were higher in the APRI, FIB-4, GUCl and King's score methods than in the other methods. The NPV value $>90 \%$ and the very low PPV level found in this study support the fact that these methods can be used effectively in the identification of truly healthy persons. This can be explained by the greater number of patients with mild fibrosis being included in this study. As with other studies, the method selectivity increased as the cut-off value used increased $(5,6,7,8)$.

The APRI, FIB-4, GUCl, and King's score have also been used by other researchers in the determination of fibrosis in patients with chronic hepatitis. In the APRI method, the AUC was in the range of $0.66-0.73(15,16,17,18)$. The cut-off value was $\leq 0.5$, sensitivity was $33 \%$, specificity was $91 \%$, PPV was $90 \%$, and NPV was $37 \%$ in this method in the determination of severe fibrosis in CHB patients (15). However, as was the case in our study, if the majority of the study group consists of patients with mild fibrosis, with the same cut-off value the first three rates drop to $62.5 \%, 51.6 \%$, and $25 \%$, respectively, while the NPV raises to $84.2 \%$ (17). In the study groups where fibrosis was predominant, the capacity to select the true patients was increased with a cutoff value of 0.535 , while the sensitivity, specificity, PPV, and NPV values were $73.2 \%, 59.4 \%, 69.8 \%$, and $63.3 \%$, respectively (18).

In particular, the degree of fibrosis in the study group affects the performance of the FIB-4 method. In their study that predominantly included patients with severe fibrosis, Ucar et al. (18) calculated the sensitivity as $70.7 \%$ and the specificity as $62.5 \%$ using the FIB-4 method, however, our study values were higher. Erdogan et al. (19) found a specificity of $58.8 \%$ in their study group, which was similar to our result. Since the AUC was higher in the present research, our sensitivity and specificity values were at a more acceptable level. The closer the AUC value is to 1, the higher the predictive value of the test (20).

Unlike the other methods, it is possible to evaluate the synthesis function of the liver using the $\mathrm{GUCl}$, which includes prothrombin time in the calculations. In our study, the AUC and the other performance characteristics of this test were higher than the results reported by Erdogan et al. (19).

With regard to the King's score, the factor of age is added to the calculations. In a study using this method in $\mathrm{CHB}$ patients, the AUC was 0.770 , sensitivity was $60 \%$, specificity was $83 \%$, PPV was $66 \%$, and NPV was $76 \%$. In that study, the King's score was reported to show the best performance in detecting fibrosis, when compared with the APRI, CDS, and AP. In the same study, similar to that in the CHB patients, the AUC was 0.783 , sensitivity was $61 \%$, specificity was $84 \%$, PPV was $75 \%$, and NPV was $72 \%$ in chronic hepatitis $\mathrm{C}(\mathrm{CHC})$ patients. However, the performance of King's score in the $\mathrm{CHC}$ patients was not found to be superior, as it was in CHB patients (21). In another study conducted with $\mathrm{CHC}$ patients, more successful results were obtained with the King's scores than the other methods in terms of the AUC, specificity, PPV, and LR+ values (22).

To the best of our knowledge, evaluation of the King's score method, which is not frequently used in $\mathrm{CHB}$ patients, and determination of its performance (more successful) is a distinctive feature of our study. However, since $\mathrm{CHC}$ patients were not included, we could not compare the effectiveness of this method with that in $\mathrm{CHB}$ patients. Another limitation of our study was that cirrhotic patients were not included in the study group. This was not due to a selective approach, but rather, because no cirrhotic patients were encountered during the study period. Moreover, since the study was performed in two centers, evaluation of fibrosis by two different pathologists may also be a limitation.

\section{Conclusion}

The highest AUC and LR+ values were obtained with the King's score in our study group, however, no significant differences were observed in terms of the other performances. When comparing our results with those of other studies King's score was found to perform superior to or similar with the other methods. It can be said that the King's score is more selective in classifying $\mathrm{CHB}$ patients with severe fibrosis, because the correct predictive value of this method is higher. Performing a similar study comparing cirrhotic patients may improve the performance of this method, because it would better demonstrate the overall effectiveness of the noninvasive methods.

\section{Ethics}

Ethics Committee Approval: This research was approved by the Etimesgut Military Hospital's Local Ethics Committee (07.07.2015-2015/21), Informed Consent: The Declaration of Helsinki and Good Clinical Practice Guidelines were respected during the entire process of enrolling the patients in the study and collecting/analyzing/ reporting the data.

Peer-review: External and Internal peer-reviewed.

\section{Authorship Contributions}

Concept: Z.K., Design: Z.K., Data Collection or Processing: Z.K., Ö.A., F.Y.K., Analysis or Interpretation: Z.K., Literature Search: Z.K., Writing: Z.K.

Conflict of Interest: No conflict of interest was declared by the authors.

Financial Disclosure: The authors declared that this study has received no financial support.

\section{References}

1. Castera L. Hepatitis B: Are non-invasive markers of liver fibrosis reliable? Liver Int. 2014;34(Suppl 1):91-96.

2. Grigorescu M. Noninvasive biochemical markers of liver fibrosis. J Gastrointestin Liver Dis. 2006;15:149-159.

3. Baranova A, Lal P, Birerdinc A, Younossi ZM. Non-invasive markers for hepatic fibrosis. BMC Gastroenterol. 2011;11:1-15.

4. Ishak K, Zimmerman H. Morphologic spectrum of drug-induced hepatic disease. Gastroenterol Clin North Am. 1995;24:759-786.

5. Wai CT, Greenson JK, Fontana RJ, Kalbfleisch JD, Marrero JA, Conjeevaram HS, Lok AS. A simple noninvasive index can predict both significant fibrosis and cirrhosis in patients with chronic hepatitis C. Hepatology. 2003;38:518-526.

6. Sterling RK, Lissen E, Clumeck N, Sola R, Correa MC, Montaner J, S Sulkowski M, Torriani FJ, Dieterich DT, Thomas DL, Messinger D, Nelson M; APRICOT Clinical Investigators. Development of a simple noninvasive index to predict significant fibrosis in patients with HIV/HCV coinfection. Hepatology. 2006;43:13171325 . 
7. Islam S, Antonsson L, Westin J, Lagging M. Cirrhosis in hepatitis $C$ virus-infected patients can be excluded using an index of standard biochemical serum markers. Scand J Gastroenterol. 2005:40:867-872.

8. Cross TJ, Rizzi P, Berry PA, Bruce M, Portmann B, Harrison PM. King's Score: an accurate marker of cirrhosis in chronic hepatitis C. Eur J Gastroenterol Hepatol. 2009;21:730-738.

9. Hsieh $Y-Y$, Tung $S-Y$, Lee $I-L$, Lee $K$, Shen $C-H$, Wei K-L, Chang TS, Chuang CS, Wu CS, Lin YH. FibroQ: An easy and useful noninvasive test for predicting liver fibrosis in patients with chronic viral hepatitis. Chang Gung Med J. 2009;32:614-622.

10. Williams A, Hoofnagle J. Ratio of serum aspartate to alanine aminotransferase in chronic hepatitis. Relationship to cirrhosis. Gastroenterology. 1988;95:734-739.

11. Bonacini M, Hadi G, Govindarajan S, Lindsay K. Utility of a discriminant score for diagnosing advanced fibrosis or cirrhosis in patients with chronic hepatitis C virus infection. Am J Gastroenterol. 1997;92:1302-1304.

12. Poynard T, Bedossa P. Age and platelet count: a simple index for predicting the presence of histological lesions in patients with antibodies to hepatitis C virus. METAVIR and CLINIVIR Cooperative Study Groups. J Viral Hepat. 1997;4:199-208.

13. Afdhal N, McHutchison J, Brown R, Jacobson I, Manns M, Poordad F, Weksler B, Esteban R. Thrombocytopenia associated with chronic liver disease. J Hepatol. 2008;48:1000-1007.

14. Tan $Y, Y e Y$, Zhou $X$, Chen $L$, Wen $D$. Age as a predictor of significant fibrosis features in $\mathrm{HBeAg}$-negative chronic hepatitis $\mathrm{B}$ virus infection with persistently normal alanine aminotransferase. PLoS One. 2015;10:1-17.
15. Yetkin MA, Bulut $C$, Caydere M, Erdinc FS, Ertem GT, Kinikli S, Tülek N, Üstün H, Demiröz AP. Aspartate Aminotransferase to Platelet Ratio Index for the Evaluation of Fibrosis in Chronic Viral Hepatitis. Flora. 2006;11:193-199.

16. Shoaei SD, Sali S, Karamipour M, Riahi E. Non-invasive histologic markers of liver disease in patients with chronic hepatitis B. Hepat Mon. 2014;14:e14228.

17. Kaya O, Akcam FZ, Sonmez Y, Tigli A, Ciris M. Evaluation of Noninvasive Methods for Prediction of Fibrosis in Chronic Hepatitis B and C Infections. Viral Hepat J. 2009;14:91-97.

18. Ucar F, Sezer S, Ginis Z, Ozturk G, Albayrak A, Basar O, Ekiz F, Coban S, Yuksel O, Armutcu F, Akbal E. APRI, the FIB-4 score, and Forn's index have noninvasive diagnostic value for liver fibrosis in patients with chronic hepatitis B. Eur J Gastroenterol Hepatol. 2013;25:1076-1081.

19. Erdogan S, Dogan HO, Sezer S, Uysal S, Ozhamam E, Kayacetin $S$, Koca $Y$. The diagnostic value of non-invasive tests for the evaluation of liver fibrosis in chronic hepatitis B patients. Scand J Clin Lab Invest. 2013;73:300-308.

20. Akturk Z, Acemoglu H. Duyarlılık ve özgüllük (ROC) analizi. In: Sağlık çalıșanları için araştırma ve pratik istatistik. 2.baskı. Istanbul: Anadolu Matbaası; 2011. p. 271-6.

21. Eminler AT, Ayyildiz T, Irak K, Kyc M, Gurel S, Dolar E, Gulten M, Nak SG. AST/ALT ratio is not useful in predicting the degree of fibrosis in chronic viral hepatitis patients. Eur J Gastroenterol Hepatol. 2015;27:1361-1366.

22. Gokcan H, Kuzu UB, Oztas E, Saygili F, Oztuna D, Suna N, Tenlik I, Akdoğan M, Kaçar S, Kılıç ZM, Kayaçetin E. The predictive value of noninvasive serum markers of liver fibrosis in patients with chronic hepatitis C. Turk J Gastroenterol. 2016;27:156-164. 